Old Age and Political Behavior 

A Publication of the Institute of Industrial Relations

University of California

\section{Old Age and}

\section{Political Behavior}

A CASE STUDY

FRANK A. PINNER, PAUL JACOBS

AND PHILIP SELZNICK

Berkeley and Los Angeles, 1959 UNIVERSITY OF CALIFORNIA PRESS 
UNIVERSITY OF CALIFORNIA PRESS BERKELEY AND LOS ANGELES

CALIFORNIA

CAMBRIDGE UNIVERSITY PRESS LONDON, ENGLAND

(C) $1959, \mathrm{BY}$

THE REGENTS OF THE UNIVERSITY OF CALIFORNIA LIBRARY OF CONGRESS CATALOG CARD NUMBER: 59-11315 PRINTED IN THE UNITED STATES OF AMERICA 